\title{
BCC and the Secret Lives of Patched: Insights from Patched Mouse Models
}

\author{
Zhu Juan Li and Chi-chung Hui \\ Program in Developmental and Stem Cell Biology, Hospital for Sick Children and \\ Department of Molecular Genetics, University of Toronto
}

Canada

\section{Introduction}

The Hedgehog $(\mathrm{Hh})$ signaling pathway is critical for growth control and patterning during embryonic development and adult homeostasis (Jiang and Hui 2008). The identification of loss-of-function mutations in PATCHED1 (PTCH1) as the underlying cause of nevoid basal cell carcinoma syndrome (Gorlin 2004), which predisposes patients to the development of neoplasms including basal cell carcinoma (BCC), first implicated the involvement of the $\mathrm{Hh}$ pathway in tumorigenesis (Johnson et al., 1996; Hahn et al., 1996). PTCH1 is a Hh-binding membrane receptor and functions as a major negative regulator of the pathway by inhibiting the signaling membrane protein SMOOTHENED (SMO). Inactivating mutations in PTCH1 as well as activating mutations in SMO are commonly found in BCC, and it is well established that abnormal Hh pathway activation is the underlying cause of BCC (Reifenberger et al., 2005; Ruiz i Altaba, 2006). However, how pathway activation disrupts normal skin homeostasis to promote BCC formation remains poorly understood.

This chapter provides an overview of the Hh pathway and the role of Ptc receptors during normal skin homeostasis and tumorigenesis. The Patched mouse model provides an excellent tool to study BCC pathogenesis since these mice recapitulate many clinical features of human BCC. In addition, the mouse Ptc1 protein is $95 \%$ identical to its human counterpart PTCH1. Examples of how Patched mouse models have facilitated our understanding of the molecular genetic and cellular events of BCC biology will be discussed. In particular, we will focus on studies performed to tease out the biological function of the C-terminal domain of Ptc and its role not only in tumorigenesis but also stem cell biology and cell cycle progression.

\section{Patched: The link between $B C C$ and Hh signaling}

BCC typically arises in sun-exposed skin and is the most commonly diagnosed cancer in the Caucasian population, with over one million people diagnosed every year in the United States. Despite the high incidence, mortality rate is low, as BCCs rarely metastasize and are generally locally invasive. The vast majority of BCCs arise sporadically, although some are attributed to a genetic predisposition syndrome. NBCCS (Nevoid basal cell carcinoma syndrome, also known as Basal-cell syndrome or Gorlin syndrome, OMIM\#109400) is a rare autosomal dominant disease in which individuals display a spectrum of developmental 
disorders including skeletal malformations, neural tube closure defects, and general overgrowth of the body (Gorlin 2004, Gorlin and Goltz 1960). These patients are highly susceptible to medulloblastoma (MB) of the cerebellum, rhabdomyosarcoma (RMS) of the soft tissue and more frequently BCC.

A link between BCC and the Hh signaling pathway was discovered in 1996, when two independent groups used positional cloning to identify germline mutations in PTCH1 (9q22.3) in patients with NBCCS and sporadic BCC (Johnson et al., 1996; Hahn et al., 1996). This discovery was seminal in understanding the genetic underpinnings of BCC and aided researchers in developing a suitable animal model. Transgenic mice that overexpress Sonic hedgehog $(\mathrm{SHH})$, the ligand for PTCH1, in the skin develop many features of NBCCS including BCC (Oro et al., 1997). In subsequent years, activating mutations in SMO were reported in patients with sporadic BCC (Xie et al., 1998). These studies highlight the importance and close connection between Hh signaling and BCC biology.

\subsection{Hh signaling in the skin}

Vertebrate $\mathrm{Hh}$ signal transduction occurs in the primary cilium, a microtubule-rich organelle that protrudes from the cell surface of virtually all mammalian cells (reviewed in Goetz and Anderson 2010). Many key components of the Hh pathway are localized to the cilium and, in response to Hh stimulus, they dynamically shuttle in or out of this organelle (May et al., 2005). In vertebrates, there are three Hh ligands: Sonic hedgehog (Shh), Dessert $\mathrm{Hh}$ (Dhh) and Indian Hh (Ihh). While Shh is more broadly expressed in tissues, including the skin, neural tube and the limb, the action and expression of other ligands are more restricted: Dhh in the testis and Ihh in the bone. In the absence of the Hh ligand, Ptc is found at the base of the primary cilium and it acts to inhibit the activity of an obligatory transmembrane protein Smo, which normally resides in intracellular vesicles (Figure 1). The binding of Hh to Ptc promotes its migration out of the cilium, allowing the activation and translocation of Smo to the tip. Though the mechanism is unclear, Smo signals downstream to generate activator forms of Gli transcription factors that turn on the expression of Hhtarget genes, such as Ptc1 and Gli1 (Figure 1). Mutation in components of the intraflagellar transport (IFT) machinery, which is required for cilia production and maintenance, leads to patterning defects in Hh-dependent tissues such as the neural tube and the limb (Huangfu and Anderson 2005; Liu et al., 2005). Depending on the tissue, loss of IFT function during embryogenesis can result in low or high Hh activity as IFTs are required to generate both activator and repressor forms of Gli transcription factors (Huangfu and Anderson 2005; Liu et al., 2005; May et al., 2005). The dual function of cilia on Hh signaling is also revealed in adult tissue homeostasis since removal of cilia could promote as well as suppress Hh-driven BCC depending on the oncogenic context (Wong et al., 2009). This action is not tissuedependent as it is also observed in other Hh-driven tumors such as MB (Han et al., 2009).

There are three Gli proteins in the mammalian Hh signaling pathway. Among them, Gli2 is the major mediator of Shh signaling during skin development and tumorigenesis (Mill et al., 2003). Gli2 $\%$ mice display hair follicle growth arrest similar to Shh- mutants and overexpression of Gli2 drives BCC development and supports tumor growth (Mill et al., 2003; Hutchin et al., 2005; Grachtchouk et al., 2000). In addition, the level of Gli activity can determine tumor type and latency (Huntziker et al., 2006; Grachtchouk et al., 2001). How Gli2 is regulated in the skin is unclear, however recent studies have demonstrated that 
Suppressor of fused (Sufu) and Kif7 are evolutionarily conserved regulators of Gli transcription factors. Sufu, like Ptc, acts as a major negative regulator of the Hh pathway and in vitro studies revealed that Sufu inhibits Gli-dependent transcription by anchoring Gli2 in the cytoplasm to prevent its access to the nucleus (Humke et al., 2010; Tukachinsky et al., 2010). Upon Hh stimulus, Gli dissociates from Sufu and translocates freely to the nucleus to activate Hh-target gene transcription (Humke et al., 2010; Tukachinsky et al., 2010). SUFU mutations have been identified in patients with sporadic BCC; however, these are accompanied by additional mutations including PTCH and TRP53 (p53). Therefore, it is difficult to determine whether SUFU mutations are the driver or merely passenger mutations (Reifenberger et al., 2005). Complete ablation of Sufu in mice leads to embryonic lethality and there is conflicting data as to whether Sufu+- mice are prone to skin tumors (Svard et al., 2006; Cooper et al., 2005; Lee et al., 2007). Analysis of Sufu deletion specifically in the skin will be useful to resolve this issue. Another regulator of Gli proteins is Kif7, a kinesin molecule that acts predominantly as a negative regulator of the $\mathrm{Hh}$ pathway (Cheung et al., 2009; Liem et al., 2009; Endoh-Yamagami et al., 2009). Kif7 is localized to the base of cilia when the pathway is inactive and it translocates to the cilia tip upon pathway activation (Endoh-Yamagami et al., 2009; Liem et al., 2009). Upon Hh stimulus, Kif7 is required for the accumulation of Gli2 and Gli3 to the cilia tip (Endoh-Yamagami et al., 2009; Liem et al., 2009), but the molecular significance of this action has yet to be determined, and whether Kif7 plays a role in the skin remains unknown. Since the activity of the Hh pathway ultimately culminates on the Gli proteins, studying how molecules regulate Gli2 is critical for our understanding of the molecular events of BCC pathogenesis.
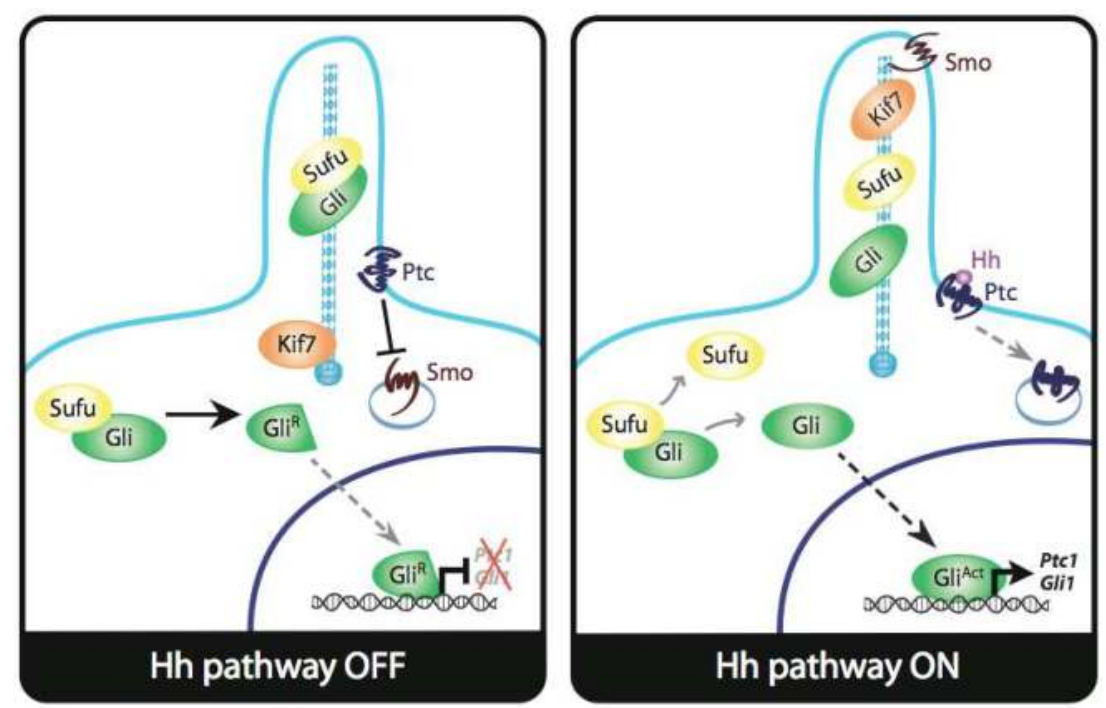

Fig. 1. Vertebrate Hh signal transduction. See text for details.

\section{Patched receptors and Patched animal models of BCC}

Human BCCs are difficult to culture and classical mouse models of skin tumors often develop other skin tumors and not BCC. This has in many ways hampered efforts to 
understand BCC pathogenesis. It was not until the generation of the $\mathrm{Ptc1}{ }^{+-}$mice that $\mathrm{BCC}$ research truly began to advance. $P t c 1^{+/-}$mice display many features of NBCCS and develop BCC (upon ionizing or ultraviolet (UV) radiation) that has many clinical and histochemical features of its human tumor counterparts: slow progression, local invasiveness, and lack of metastasis (Aszterbaum et al., 1999; Mancuso et al., 2004). This model facilitated the identification of both the genetic events and the molecular basis of BCC. Table 1 outlines the current models of BCC using Ptc mutant mice. Next, we will describe how the Ptc1 mutant mouse model revealed the temporal importance of proliferation for BCC formation as well as gave insight into the genetic control, molecular events and the cell of origin of BCC.

\subsection{The Patched family members: Patched1 and Patched2}

Ptc receptors contain 12 hydrophobic membrane-spanning domains, two large hydrophilic extracellular loops as well as intracellular amino- and carboxyl-terminal regions (Figure 2). The Ptc receptors have a sterol-sensing domain (SSD) and belong to a family of integral-membrane proteins (Kuwabara and Labouesse 2002). SSDs are implicated in vesicle trafficking and cholesterol homeostasis. In addition, the predicted transmembrane topology of Ptc is similar to the resistance nodulation division (RND) family of prototypic bacterial multidrug efflux pumps. RND proteins in bacteria typically transport substrates from the cytoplasm to the extracellular space. How Ptc inhibits Smo is not well understood but it is not likely through direct physical interactions since Ptc can inhibit a large stoichiometric excess of Smo (Taipale et al., 2002). One possibility is that Ptc could function as a molecular transporter for a small molecule that directly binds to or regulates Smo activity. In agreement with this notion, natural and synthetic molecules can modulate the ability of Smo to activate the Hh pathway (Chen et al, 2002).

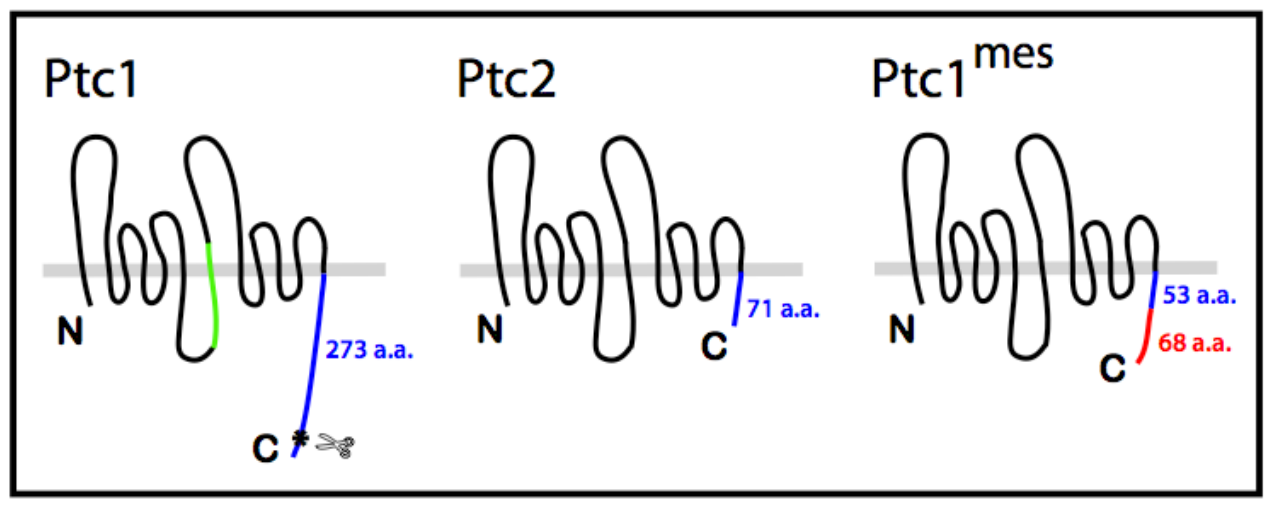

Fig. 2. Topological models of the mouse Ptc receptors. The two large extracellular loops of Ptc receptors bind to the Hh ligands. The CTD of Ptc1 is 273 amino acids in length while the CTD of Ptc2 only extends to 71 amino acids (blue). Green denotes the proposed cyclin B1 interacting domain of Ptc1 (amino acids 690-779) Amino acids 690-779 of Ptc1 is 51\% identical to a similar region on Ptc2. Ptc1 mes protein retains the first 53 amino acids (blue) of the C-terminal cytoplasmic domain and gains a missence mutation of 68 amino acids (red); therefore, lacks most of its CTD. Predicated caspase-cleavage site (asterisks). 


\begin{tabular}{|c|c|c|c|}
\hline Mutant & Type of mutation & Phenotype & References \\
\hline Ptc1+/- & $\begin{array}{l}\text { Loss of function (in-frame } \\
\text { fusion of } l a c Z \text { reporter to } \\
\text { exons } 1 \text { and } 2 \text { ) }\end{array}$ & $\begin{array}{l}\text { Features of NBCCS and increased } \\
\text { susceptibility to spontanous tumor } \\
\text { development (RMS and MB) } \\
\text { Low frequency of spontanous } \\
\text { trichoblastoma-like tumors } \\
\text { Enhanced tirchoblastoma-like tumors } \\
\text { and microscopic BCC-like lesions were } \\
\text { observed after ultraviolet or ionizing } \\
\text { radiation }\end{array}$ & $\begin{array}{l}\text { Goodrich } \\
\text { et al., 1997; } \\
\text { Aszterbaum } \\
\text { et al., 1999; }\end{array}$ \\
\hline Ptc1neo67/+ & $\begin{array}{l}\text { Loss of function (deletion } \\
\text { of exons } 6 \text { and } 7 \text { ) }\end{array}$ & $\begin{array}{l}\text { Features of NBCCS and increased } \\
\text { susceptibiilty to spontanous tumor } \\
\text { development (RMS and MB) } \\
\text { Non-irradiated mice develop basaloid } \\
\text { hyperproliferation in the skin } \\
\text { Irradiated mice develop nodular and } \\
\text { iniltrative BCC-like tumors }\end{array}$ & $\begin{array}{l}\text { Hahn } \\
\text { et al., 1998; } \\
\text { Mancuso } \\
\text { et al., } 2004\end{array}$ \\
\hline Ptc1mes/mes & $\begin{array}{l}\text { Deletion of the most C- } \\
\text { terminal cytoplasmic } \\
\text { domain }\end{array}$ & $\begin{array}{l}\text { Excess skin; basal cell layer hyperplasia } \\
\text { and expansion of the epidermal stem } \\
\text { cell compartment in adult skin }\end{array}$ & $\begin{array}{l}\text { Makino } \\
\text { et al., 2001; } \\
\text { Nieuwenhuis } \\
\text { et al., } 2007\end{array}$ \\
\hline Ptc1flox/flox & Conditional allele & $\begin{array}{l}\text { BCC develops when crossed to skin- } \\
\text { specific promoters of Cre (K6-Cre, K14- } \\
\text { Cre, K5-CrePR1, and Lgr5-CreERT2) }\end{array}$ & $\begin{array}{l}\text { Adolphe } \\
\text { et al., } 2006 \\
\text { Villani } \\
\text { et al., } 2010 \\
\text { Kasper } \\
\text { et al., } 2011\end{array}$ \\
\hline Ptc1D11 & $\begin{array}{l}\text { Weak allele, effect on gene } \\
\text { and protein product is } \\
\text { unknown }\end{array}$ & $\begin{array}{l}\text { Ptc1 homozygous mice are sterile but } \\
\text { appears normal }\end{array}$ & $\begin{array}{l}\text { Oro and } \\
\text { Higgins, } \\
2003\end{array}$ \\
\hline PtcB6 & $\begin{array}{l}\text { Polymorphism the C- } \\
\text { terminus (T1267N) of Ptc1 } \\
\text { allele found in C57BL/6 } \\
\text { background mice } \\
\text { compared to FVB/N mice }\end{array}$ & $\begin{array}{l}\text { C57BL/ } 6 \text { mice are resistant to } \\
\text { squamouse cell carcinoma induced by } \\
\text { activated Ras }\end{array}$ & $\begin{array}{l}\text { Wakabayashi } \\
\text { et al., } 2007\end{array}$ \\
\hline Ptc2-/- & $\begin{array}{l}\text { Truncated Ptc2 mRNA } \\
\text { (deletion of exons 5-17), } \\
\text { effect on protein product is } \\
\text { unknown }\end{array}$ & $\begin{array}{l}\text { No discernable skin defect; however, } \\
\text { Ptc } 1 \text { and } P t c 2 \text { compound mutants have } \\
\text { increased tumor susceptiblity } \\
\text { compared to Ptc1 mutants }\end{array}$ & $\begin{array}{l}\text { Lee } \\
\text { et al., } 2006\end{array}$ \\
\hline Ptc2tm1/tm1 & $\begin{array}{l}\text { Hypomorphic allele } \\
\text { (disruption of exon } 6 \text { ), with } \\
\text { several truncated Ptc2 } \\
\text { mRNA products produced, } \\
\text { effect on protein product is } \\
\text { unknown }\end{array}$ & $\begin{array}{l}\text { Male-specific alopecia, ulceration and } \\
\text { epidermal hyperplasia with } \\
\text { progressing age }\end{array}$ & $\begin{array}{l}\text { Nieuwenhuis } \\
\text { et al., } 2006\end{array}$ \\
\hline
\end{tabular}

Abbreviations: BCC, basal cell carcinoma; NBCCS, nevoid basal cell carcinoma syndrome; MB, medulloblastoma; RMS, rhabdomyosarcoma

Table 1. Summary of Genetic Analyses of Ptc function in the mouse skin. 
There are two Ptc genes in vertebrates: Ptc1 and Ptc2. PTCH2/Ptc2 encodes a protein with $45 \%$ identity to PTCH1/Ptc1 and contains much shorter intracellular amino- and carboxyterminal regions than Ptc1 (Figure 2). They also differ in the hydrophilic loop between transmembrane domain 6 (TM6) and TM7. Hh ligands bind to the two extracellular loops of PTCH1 and PTCH2 with similar affinity (Carpenter et al., 1998; Marigo et al., 1996). Both Ptc1 and Ptc2 inhibit Hh pathway activity in the absence of ligand, however whether this inhibition is equivalent has not been determined. $\mathrm{PTCH} 2$ mutations were found in some cases of sporadic BCC, and a PTCH2 germline mutation was identified in a family with NBCCS (Fan et al., 2008; Smyth et al., 1999). This suggests that Ptc2 has a role in development and possibly tumor suppression. We found that Ptc2-deficient $\left(P_{t c 2}{ }^{t m 1 / t m 1}\right)$ mice are viable, fertile and do not develop any obvious developmental defects in Hh-responding tissues, such as the hair follicle, limb, neural tube or testis (Nieuwenhuis et al., 2006). However, with age, adult male Ptc ${ }^{\operatorname{tm} 1 / t m 1}$ mice develop epidermal hyperplasia and hair loss. Ptc2-deficient mice are not cancer prone but, in the $\mathrm{Ptc1}^{+-}$- background, Ptc2+- and Ptc2mice showed a higher incidence of tumors including BCC when compared to $\mathrm{Ptc1}^{+/-}$mice (Lee et al., 2006). These studies demonstrate that Ptc2 is required during adult skin homeostasis and possesses overlapping functions with Ptc1 in tumor suppression. The divergence of Ptc receptor expression patterns and levels may reflect their unique and overlapping roles during embryogenesis and in maintenance of adult tissues such as the skin (Carpenter et al., 1998; Motoyama et al., 1998; Nieuwenhuis et al., 2006).

\subsection{Insights gained from Patched animal models}

$\mathrm{Ptc1}^{+-}$mice in many regards recapitulate the typical pathologies associated with NBCCS, including a higher sensitivity to spontaneous tumorigenesis (Aszterbaum et al., 1999; Goodrich et al., 1996). The vast majorities of these tumors are MB and RMB, and at a low frequency, skin tumors. When these mice are exposed to UV or ionizing radiation, BCC-like lesions form, suggesting that additional genetic alterations, possibly caused by DNA damage, are required to promote BCC progression. Consistent with this notion, human BCC typically occur in sun-exposed areas of the skin and BCC with PTCH1 mutation are frequently associated with mutations in $p 53$, a tumor suppressor gene that is mutated in over $50 \%$ of all human tumors (Ponten et al., 1997; Zhang et al., 2001). Furthermore, BCC formation in $\mathrm{Ptc1}^{+-}$mice was enhanced upon the ablation of $p 53$ in the skin, suggesting that Ptc1 mutations synergize with the loss of p53 to promote BCC (Wang et al., 2011). Intriguingly, loss of p53 induces the expression of Smo, an obligatory signal transducer of the pathway in the interfollicular epidermis (IFE), where Smo expression is normally not detected (Wang et al., 2011). How p53 contributes to BCC development is unclear but this finding suggests that loss of p53 may promote BCC through its effects on the expression of Hh components. Another genetic signature found in BCC is the loss of heterozygosity ( $\mathrm{LOH}$ ) at the PTCH1 locus and NBCCS patients with BCC have the remaining somatic wild-type PTCH1 allele mutated or deleted (Teh et al., 2005). Similarly, LOH at the Ptc1 locus is observed in tumors of $P t c 1+/-$ mice after exposure to UV or ionizing radiation, further illustrating that DNA damaging agents are a strong etiological factor in BCC (Aszterbaum et al., 1999). Whether inactivation of the second allele of $\mathrm{PTCH} 1$ is required for $\mathrm{BCC}$ formation could not be conclusively addressed using Ptc1 ${ }^{+/-}$models. Using Ptc1 conditional knockout mice, it was reported that mice develop BCC only upon biallelic loss of Ptc1 whereas monoallelic inactivation of Ptc1 is not sufficient to induce tumorigenesis (Zibat et al., 2009; Kasper et al., 
2011). These studies have revealed that Ptc1 is a classical tumor suppressor gene and follows Knudson's two hit hypothesis that germline mutation in the PTCH1 locus requires a "second hit" for tumorigenesis to occur (Knudson 1996).

Interestingly, the frequency of BCC and histological BCC subtypes that develop in Ptc1+mice correlates with the phase of the hair follicle cycle at the time of irradiation. In the adult skin, the hair undergoes cyclic nature of active growth (anagen), regression (catagen) and rest (telogen) (Figure 3A). Hair follicle keratinocytes at anagen are highly proliferative since they are required to generate a new follicle at each hair cycle. Shh pathway activation acts as a biological switch for the transition from telogen to anagen. Shh is only detectable during anagen and is transcribed asymmetrically in the distal growing tip of the hair follicle, while in the IFE, little to no expression of Shh or Hh target genes is detected (Oro and Higgins 2003). During anagen, Hh target genes are expressed in the hair matrix and dermal papilla suggesting that these cells represent Hh-responding cells (Oro and Higgins 2003). As the hair degenerates, Ptc1 and Gli1 expression decrease and becomes undetectable at telogen (Oro and Higgins 2003). Ptc1 ${ }^{+/}$mice irradiated at anagen exhibited more advance tumor growth and much earlier tumor onset than mice irradiated at telogen (Mancuso et al., 2006). This suggests that the hair cycle-induced differences in the proliferation capability of keratinocytes can regulate BCC latency and progression.

Conditional deletion of Ptc1 in the skin has revealed possible molecular events and pathways involved in BCC. Inactivation of Ptc1 in the skin induces rapid skin tumor formation without disrupting the expression pattern of Notch signaling components and the nucleo-cytoplasmic distribution of $\beta$-catenin, key signaling molecules known to play a role in the skin (Adolphe et al., 2006). Loss of Ptc1 results in the nuclear accumulation of cell cycle regulators cyclin B1 and cyclin D1, suggesting that Ptc1 functions as a tumor suppressor in the skin in part through regulation of the G1-S and G2-M check points of the cell cycle (Adolphe et al., 2006). Consistent with this finding, Ptc1 has been shown to physically interact with cyclin B1, tethering it in the cytoplasm (Barnes et al., 2001). The authors tested the clinical significance of this interaction by generating a construct that contains a common PTCH1 mutation found in NBCCS/BCC patients, which lacks the cyclin B1-binding domain (Barnes et al., 2005). Cell culture experiments have shown that Ptc1Q688x, a mutant construct encoding a Ptc1 protein truncated at the large intracellular loop, enhances Gli1 activity, promotes proliferation and is non-responsive to Shh treatment (Barnes et al., 2005). Since Gli2 has been shown to promote the transcription of D-type cyclins, nuclear translocation of cyclin D1 is likely a consequence of activated Hh pathway rather than a direct interaction with Ptc1.

Ptc1 has also been shown to inhibit basal cell progenitor expansion possibly through limiting the activity of Insulin-like growth factor binding protein 2 (Igfbp2) (Villani et al, 2010). The function of Igfbp2 in the skin is unknown; however, there is a positive correlation between Igfbp2 expression and human BCC raising the possibility that Igfbp2 is associated with BCC (Villani et al, 2010). Whether the control on Igfbp2 activity is a Ptc1-specific function or a consequence of activated pathway activity remains unknown.

The skin is composed of functionally and biologically distinct units: hair follicle, IFE and the sebaceous gland (Figure 3B). The basal cell layer in the IFE is continuous with the outer root sheath (ORS) of the hair follicle and contains progenitor keratinocytes. Two populations of stem cells are required to maintain skin homeostasis: one that resides in the hair follicle niche, the bulge and the other dispersed in the IFE (Levy et al., 2005). Genetic lineage 
analysis demonstrated that bulge cells are capable of generating all lineages of the hair follicle to ensure proper tissue homeostasis but only contribute to IFE during wound healing (Levy et al., 2007; Ito et al., 2005). Given that the skin is composed of different cell populations, a key question that arises is what is the cell of origin of BCC? The development of molecular tools was critical to address this question. Using different cell type-specific promoters to drive Cre expression to conditionally express an activating mutation in Smo (SmoM2), Blainpain's group elegantly showed that specifically activating Hh signaling in the long-lived K14+ progenitors of the IFE induces BCC formation (Youssef et al., 2010). In contrast, $\mathrm{K} 15+$ cell fate mapping analysis on irradiated $\mathrm{Ptc}^{+} /-$model of $\mathrm{BCC}$ revealed that the majority of BCC arose from K15 expressing hair follicle bulge stem cells (Wang et al., 2011). These studies would suggest that both hair follicle stem cells (K15+) and epidermal progenitor cells $(\mathrm{K} 14+)$ are capable of tumor-initiation and that epidermal cell subpopulations are sensitive to different Hh-driven BCC mutations. Interestingly, cutaneous injury has been shown to influence the cell of origin of BCC. For example, overexpression of SmoM2 in the $\mathrm{K} 15+$ bulge cells does not lead to BCC; however, wounding can induce migration of oncogeneexpressing bulge cells to the sites of injury to promote BCC formation (Wong and Reiter 2011). Taken together, these studies illustrate that the cell of origin of BCC is context dependent, encompassing both the type of activating mutations and factors involved in wound healing.

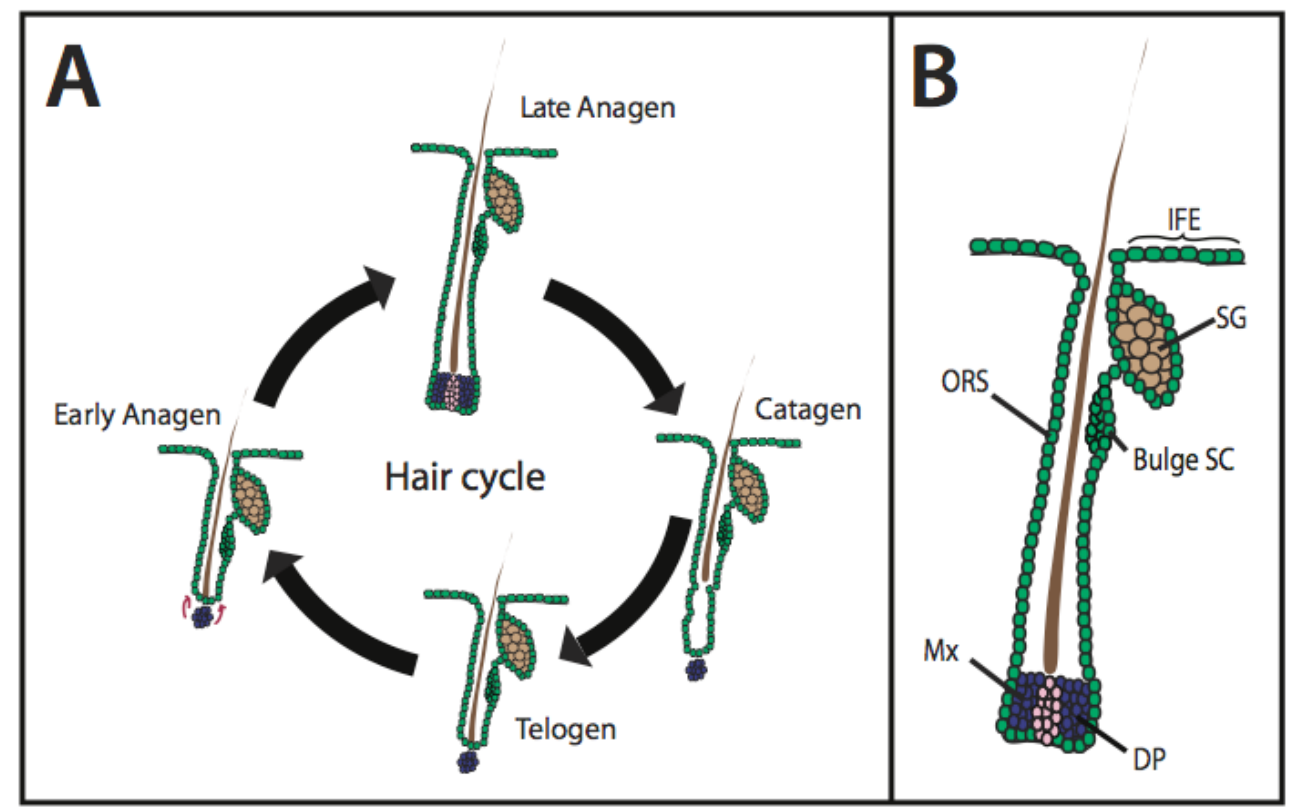

Fig. 3. Adult hair cycle. In the adult skin, the hair follicle constantly degenerates (catagen), rests (telogen) and grows (anagen). Only the non-permanent region of the hair follicle, below the bulge stem cells (SC) participates in these phases of hair cycle. Bulge SCs are located beneath the sebaceous gland (SG). Following telogen, when the dermal papilla (DP) is proximal to the permanent follicle segment, the bulge SC are activated (red arrows) to initiate a new round of hair growth by producing transiently amplifying cells/matrix cells (Mx). The matrix cells will give rise to all differentiated layers of the mature hair follicle. 


\section{C-terminal domain of Ptc1: Cell survival, cell cycle progression and stem cell maintenance in the epidermis}

Besides its ability to inhibit Hh signaling, Ptc1 has been shown to act as a dependence receptor. Dependence receptors promote cell survival when bound to their ligands and induce programmed cell death in the absence of the ligand. Overexpression of Ptc1 results in apoptosis in both cell culture and the neural tube of chick embryos and this can be reversed through addition of Shh ligand (Thibert et al., 2003). The ability of Ptc1 to induce cell death is dependent on a caspase-cleavage site located at Asp 1392, 42 amino acids from the C-terminus of Ptc1 (Figure 2) (Thibert et al., 2003; Mille et al., 2009). Interestingly, Ptc-induced cell death is not affected through expression of Smo, suggesting that Ptc's ability to induce apoptosis is independent of Ptc-Smo transduction. How Ptc transduces this survival signal downstream and whether this is dependent on the Gli transcription factors are unknown.

Interestingly, the majority of PTCH1 mutations identified in BCC result in premature truncation of the protein (Daya-Grosjean and Couve-Privat 2005). These findings raise the tantalizing possibility that the C-terminal half of PTCH1 is crucial for tumor suppression. Little is known about the C-terminal domain (CTD) of Ptc1 in the context of skin development and homeostasis. Our group aimed to address these questions by analyzing Ptc1 ${ }^{\text {mes }}$ mice. A spontaneous recessive mutation in Ptc1, mesenchymal dysplasia (mes) was found in mice containing a missense mutation resulting in a 32bp deletion and a 152 amino acid truncation of the CTD (Figure 2) (Sweet et al., 1996; Makino et al., 2001). It was reported that Ptc1mes/mes mice possess excess skin, suggesting that the CTD of Ptc1 is involved in skin development and/or homeostasis (Makino et al., 2001). We found that adult Ptc1 ${ }^{\text {mes/mes }}$ mice have severe epidermal hyperplasia starting as early as postnatal day 12 . These mice displayed hyperproliferation of the basal cell population, attributed to increased c-Myc expression, while stratification and apoptosis of the epidermis were not affected. Despite the fact that Ptc1 is a major negative regulator of Hh signaling, Ptc1mes/mes mice displayed normal pathway activity in the epidermis, and the Ptc1 mes protein maintained similar Shh-binding abilities to wild-type Ptc1. These data suggest that the function of the CTD is independent of Shh pathway/Gli activity. Normally, epidermal stem cells rarely divide and reside in two functionally distinct locations in the skin: the bulge and the IFE. Using BrdU pulse-chase labeling, we found that Ptc1mes/mes epidermis exhibited an increase in the number of labelretaining cells (i.e. quiescent stem cells) in the IFE, indicating that the CTD is required for epidermal stem cell maintenance (Figure 4). Despite the persistent hyperplasia phenotype, Ptc1 ${ }^{\text {mes/mes }}$ mice do not develop skin tumors even in response to the DNA damaging effects of radiation (unpublished data). It has been reported that the level of Hh pathway activity determines tumor outcome, ranging from epidermal hyperplasia to BCCs. Therefore we speculate that the lack of tumorigenesis may be attributed to normal Hh pathway activity observed in Ptc1mes/mes adult mice. As wounding can contribute to tumor outcome, it would be interesting to determine whether injury can promote tumorigenesis in the mes background. Given that $P t c 1^{+/}$mice are more susceptible to tumorigenesis, whether the mes mutation can modulate tumorigenesis of $\mathrm{Ptcl}^{+} /$mice remains to be determined. Together, our study revealed a novel, unexpected role for the CTD of Ptc1 in the regulation of epidermal homeostasis. Furthermore, it highlights a non-canonical function of Ptc1, which appears to be independent of Gli activity. 

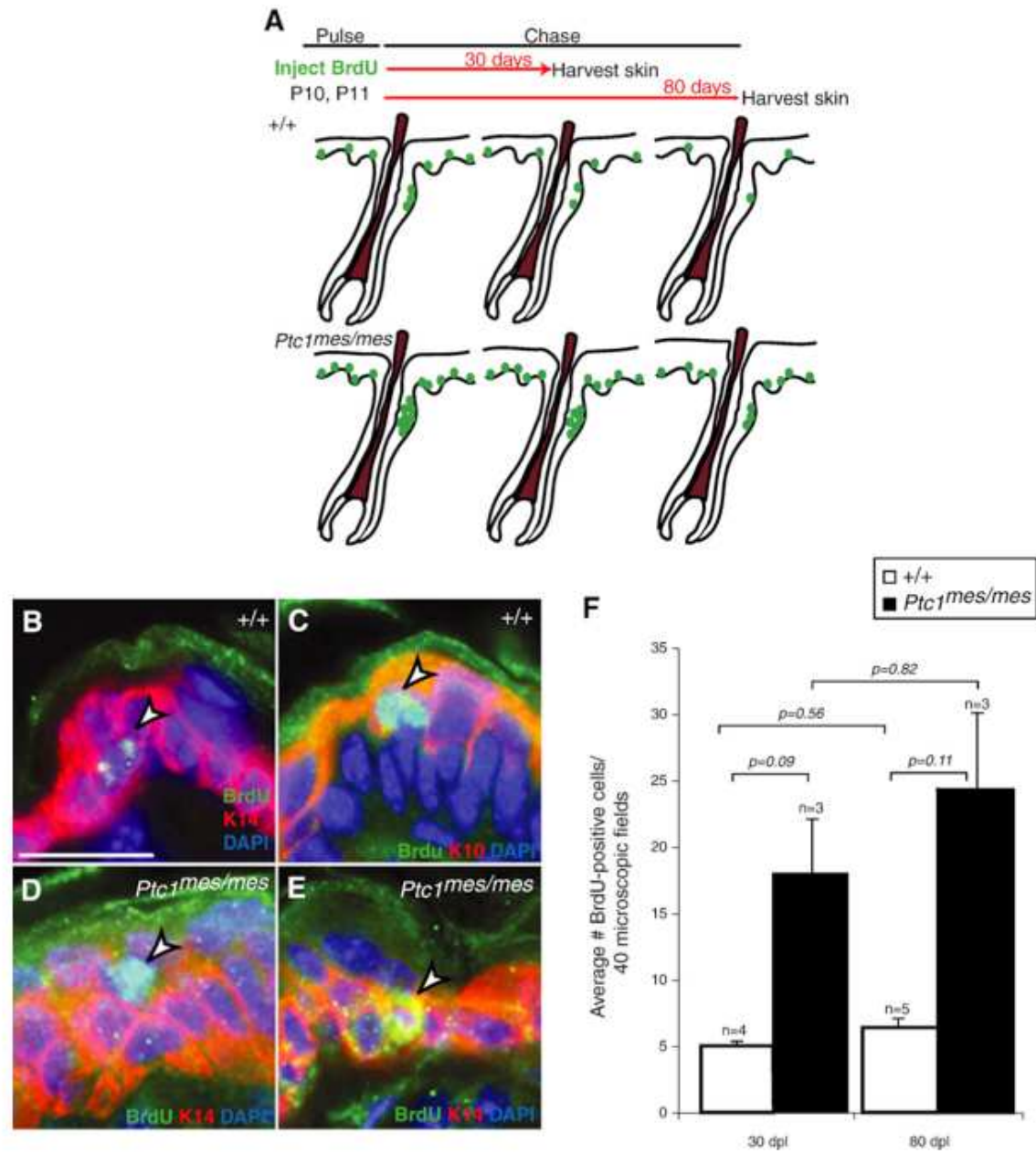

Fig. 4. Ptc1 $1^{\text {mes/mes }}$ epidermis exhibits an increase in the number of label-retaining cells. (A) Schematic diagram illustrating pulse-chase experiment. Ten-day-old wild-type and Ptc1mes/mes pups received four consecutive BrdU injections at 12-hour intervals to label all mitotic cells. Skin samples were collected 30 and 80 days post-labeling (dpl). (B-E) Basal cells were identified using K-14/BrdU double labelling and are considered to be labelretaining interfollicular epidermal stem cells (B, D, E; arrowheads). Suprabasal cells were identified using K-10/BrdU double labeling. These cells were not considered to be interfollicular stem cells and were not counted (C; arrowhead). (D, E) BrdU/K-14-double positive cells could be detected at 30 (D) and 80 (E) dpl in wild-type and Ptc1 ${ }^{\text {mes }} /$ mes $s k i n .(F)$ At 30 days, skin showed a 3.6-fold increase in BrdU/K14-double positive cells. A 3.3-fold increase was observed at $80 \mathrm{dpl}$. Data represent the mean \pm SEM. Scale bars $=50 \mu \mathrm{m}$. Reprinted from Developmental Biology, E.N., P.C.B., S.M., C.-c. H., Epidermal hyperplasia and expansion of the interfollicular stem cell compartment in mutant mice with C-terminal truncation of Patched1, 308, 547-560, (C) 2007, with permission from Elsevier. 


\section{Conclusion and future prospective}

The establishment of Ptc mutant mouse models of BCC has given us critical insight into the genetic underpinnings and the molecular events that drive $\mathrm{BCC}$ formation. We described here that the tumor suppressor Ptc1 is a multifaceted protein that is not solely dedicated to repressing the Hh pathway. By attempting to understand BCC biology using the Ptc1 mouse model, researchers have serendipitously stumbled upon the non-canonical functions of Ptc1. In the neural tube, Shh can act as a chemical cue to guide commissural axons independent of Gli transcription factors, further illustrating that Gli activity is not always coupled to the Shh-Ptc module (Okada et al., 2006; Yam et al., 2009). Interestingly, the non-canonical actions of Ptc1 can be traced to its C-terminal domain, which is largely absent in Ptc2, suggesting a functional divergence between the Ptc family of receptors.

Our group found that the CTD of Ptc1 is important in stem cell homeostasis of the IFE, identifying Ptc1 as a pivotal switch between quiescence or cell cycle progression (Nieuwenhuis et al., 2007). The molecular events mediating this outcome remain unclear. We speculate that the CTD of Ptc1 might act as a docking site for regulatory proteins required for stem cell maintenance. Determining these potential binding partners could help decipher the atypical functions of Ptc1. Mutations of the PTCH1 locus in BCC typically display a truncating mutation in one allele and a deletion on the other (Reichrath 2006). Further analyses on the monoallelic loss of Ptc1 in conjunction with Ptc1 point mutations will be necessary to recapitulate the molecular events leading to BCC pathogenesis, which cannot be uncovered using current Ptc mouse models.

\section{References}

Adolphe, C., R. Hetherington, T. Ellis \& B. Wainwright (2006) Patched1 functions as a gatekeeper by promoting cell cycle progression. Cancer Res, 66, 2081-8.

Aszterbaum, M., J. Epstein, A. Oro, V. Douglas, P. E. LeBoit, M. P. Scott \& E. H. Epstein, Jr. (1999) Ultraviolet and ionizing radiation enhance the growth of BCCs and trichoblastomas in patched heterozygous knockout mice. Nat Med, 5, 1285-91.

Barnes, E. A., K. J. Heidtman \& D. J. Donoghue (2005) Constitutive activation of the shh-ptc1 pathway by a patched1 mutation identified in BCC. Oncogene, 24, 902-15.

Barnes, E. A., M. Kong, V. Ollendorff \& D. J. Donoghue (2001) Patched1 interacts with cyclin B1 to regulate cell cycle progression. EMBO J, 20, 2214-23.

Carpenter, D., D. M. Stone, J. Brush, A. Ryan, M. Armanini, G. Frantz, A. Rosenthal \& F. J. de Sauvage (1998) Characterization of two patched receptors for the vertebrate hedgehog protein family. Proc Natl Acad Sci U S A, 95, 13630-4.

Chen, J. K., J. Taipale, K. E. Young, T. Maiti \& P. A. Beachy (2002) Small molecule modulation of Smoothened activity. Proc Natl Acad Sci U S A, 99, 14071-6.

Cheung, H. O., X. Zhang, A. Ribeiro, R. Mo, S. Makino, V. Puviindran, K. K. Law, J. Briscoe \& C. C. Hui (2009) The kinesin protein Kif7 is a critical regulator of Gli transcription factors in mammalian hedgehog signaling. Sci Signal, 2, ra29. 
Cooper, A. F., K. P. Yu, M. Brueckner, L. L. Brailey, L. Johnson, J. M. McGrath \& A. E. Bale (2005) Cardiac and CNS defects in a mouse with targeted disruption of suppressor of fused. Development, 132, 4407-17.

Daya-Grosjean, L. \& S. Couve-Privat (2005) Sonic hedgehog signaling in basal cell carcinomas. Cancer Lett, 225, 181-92.

Endoh-Yamagami, S., M. Evangelista, D. Wilson, X. Wen, J. W. Theunissen, K. Phamluong, M. Davis, S. J. Scales, M. J. Solloway, F. J. de Sauvage \& A. S. Peterson (2009) The mammalian Cos2 homolog Kif7 plays an essential role in modulating Hh signal transduction during development. Curr Biol, 19, 1320-6.

Fan, Z., J. Li, J. Du, H. Zhang, Y. Shen, C. Y. Wang \& S. Wang (2008) A missense mutation in PTCH2 underlies dominantly inherited NBCCS in a Chinese family. J Med Genet, 45, 303-8.

Goetz, S. C. \& K. V. Anderson (2010) The primary cilium: a signalling centre during vertebrate development. Nat Rev Genet, 11, 331-44.

Goodrich, L. V., R. L. Johnson, L. Milenkovic, J. A. McMahon \& M. P. Scott (1996) Conservation of the hedgehog/patched signaling pathway from flies to mice: induction of a mouse patched gene by Hedgehog. Genes Dev, 10, 301-12.

Gorlin, R. J. \& R. W. Goltz (1960) Multiple nevoid basal-cell epithelioma, jaw cysts and bifid rib. A syndrome. N Engl J Med, 262, 908-12.

Gorlin, R. J. (2004) Nevoid basal cell carcinoma (Gorlin) syndrome. Genet Med, 6, 530-9.

Grachtchouk, M., J. Pero, S. H. Yang, A. N. Ermilov, L. E. Michael, A. Wang, D. Wilbert, R. M. Patel, J. Ferris, J. Diener, M. Allen, S. Lim, L. J. Syu, M. Verhaegen \& A. A. Dlugosz (2011) Basal cell carcinomas in mice arise from hair follicle stem cells and multiple epithelial progenitor populations. J Clin Invest, 121, 1768-81.

Grachtchouk, M., R. Mo, S. Yu, X. Zhang, H. Sasaki, C. C. Hui \& A. A. Dlugosz (2000) Basal cell carcinomas in mice overexpressing Gli2 in skin. Nat Genet, 24, 216-7.

Grachtchouk, V., M. Grachtchouk, L. Lowe, T. Johnson, L. Wei, A. Wang, F. de Sauvage \& A. A. Dlugosz (2003) The magnitude of hedgehog signaling activity defines skin tumor phenotype. EMBO J, 22, 2741-51.

Hahn, H., C. Wicking, P. G. Zaphiropoulous, M. R. Gailani, S. Shanley, A. Chidambaram, I. Vorechovsky, E. Holmberg, A. B. Unden, S. Gillies, K. Negus, I. Smyth, C. Pressman, D. J. Leffell, B. Gerrard, A. M. Goldstein, M. Dean, R. Toftgard, G. Chenevix-Trench, B. Wainwright \& A. E. Bale (1996) Mutations of the human homolog of Drosophila patched in the nevoid basal cell carcinoma syndrome. Cell, 85, 841-51.

Hahn, H., L. Wojnowski, A.M. Zimmer, J. Hall, G. Miller \& A. Zimmer (1998) Rhabdomyosarcomas and radiation hypersensitivity in a mouse model of Gorlin syndrome. Nat Med, 4, 619-22.

Han, Y. G., H. J. Kim, A. A. Dlugosz, D. W. Ellison, R. J. Gilbertson \& A. Alvarez-Buylla (2009) Dual and opposing roles of primary cilia in medulloblastoma development. Nat Med, 15, 1062-5.

Huangfu, D. \& K. V. Anderson (2005) Cilia and Hedgehog responsiveness in the mouse. Proc Natl Acad Sci U S A, 102, 11325-30. 
Humke, E. W., K. V. Dorn, L. Milenkovic, M. P. Scott \& R. Rohatgi (2010) The output of Hedgehog signaling is controlled by the dynamic association between Suppressor of Fused and the Gli proteins. Genes Dev, 24, 670-82.

Huntzicker, E. G., I. S. Estay, H. Zhen, L. A. Lokteva, P. K. Jackson \& A. E. Oro (2006) Dual degradation signals control Gli protein stability and tumor formation. Genes Dev, 20, 276-81.

Hutchin, M. E., M. S. Kariapper, M. Grachtchouk, A. Wang, L. Wei, D. Cummings, J. Liu, L. E. Michael, A. Glick \& A. A. Dlugosz (2005) Sustained Hedgehog signaling is required for basal cell carcinoma proliferation and survival: conditional skin tumorigenesis recapitulates the hair growth cycle. Genes Dev, 19, 214-23.

Ito, M., Y. Liu, Z. Yang, J. Nguyen, F. Liang, R. J. Morris \& G. Cotsarelis (2005) Stem cells in the hair follicle bulge contribute to wound repair but not to homeostasis of the epidermis. Nat Med, 11, 1351-4.

Jiang, J. \& C. C. Hui (2008) Hedgehog signaling in development and cancer. Dev Cell, 15, 801-12.

Johnson, R. L., A. L. Rothman, J. Xie, L. V. Goodrich, J. W. Bare, J. M. Bonifas, A. G. Quinn, R. M. Myers, D. R. Cox, E. H. Epstein, Jr. \& M. P. Scott (1996) Human homolog of patched, a candidate gene for the basal cell nevus syndrome. Science, 272, 166871.

Kasper, M., V. Jaks, A. Are, A. Bergstrom, A. Schwager, N. Barker \& R. Toftgard (2011) Wounding enhances epidermal tumorigenesis by recruiting hair follicle keratinocytes. Proc Natl Acad Sci U S A, 108, 4099-104.

Knudson, A. G. (1996) Hereditary cancer: two hits revisited. J Cancer Res Clin Oncol, 122, 13540.

Kuwabara, P. E. \& M. Labouesse (2002) The sterol-sensing domain: multiple families, a unique role? Trends Genet, 18, 193-201.

Lee, Y., H. L. Miller, H. R. Russell, K. Boyd, T. Curran \& P. J. McKinnon (2006) Patched2 modulates tumorigenesis in patched1 heterozygous mice. Cancer Res, 66, 696471.

Lee, Y., R. Kawagoe, K. Sasai, Y. Li, H. R. Russell, T. Curran \& P. J. McKinnon (2007) Loss of suppressor-of-fused function promotes tumorigenesis. Oncogene, 26, 6442-7.

Levy, V., C. Lindon, B. D. Harfe \& B. A. Morgan (2005) Distinct stem cell populations regenerate the follicle and interfollicular epidermis. Dev Cell, 9, 855-61.

Levy, V., C. Lindon, Y. Zheng, B. D. Harfe \& B. A. Morgan (2007) Epidermal stem cells arise from the hair follicle after wounding. FASEB J, 21, 1358-66.

Liem, K. F., Jr., M. He, P. J. Ocbina \& K. V. Anderson (2009) Mouse Kif7/Costal2 is a ciliaassociated protein that regulates Sonic hedgehog signaling. Proc Natl Acad Sci U S A, 106, 13377-82.

Liu, A., B. Wang \& L. A. Niswander (2005) Mouse intraflagellar transport proteins regulate both the activator and repressor functions of Gli transcription factors. Development, 132, 3103-11. 
Makino, S., H. Masuya, J. Ishijima, Y. Yada \& T. Shiroishi (2001) A spontaneous mouse mutation, mesenchymal dysplasia (mes), is caused by a deletion of the most Cterminal cytoplasmic domain of patched (ptc). Dev Biol, 239, 95-106.

Mancuso, M., S. Leonardi, M. Tanori, E. Pasquali, M. Pierdomenico, S. Rebessi, V. Di Majo, V. Covelli, S. Pazzaglia \& A. Saran (2006) Hair cycle-dependent basal cell carcinoma tumorigenesis in Ptc1neo67/+ mice exposed to radiation. Cancer Res, 66, 6606-14.

Mancuso, M., S. Pazzaglia, M. Tanori, H. Hahn, P. Merola, S. Rebessi, M. J. Atkinson, V. Di Majo, V. Covelli \& A. Saran (2004) Basal cell carcinoma and its development: insights from radiation-induced tumors in Ptch1-deficient mice. Cancer Res, 64, 93441.

Marigo, V., R. A. Davey, Y. Zuo, J. M. Cunningham \& C. J. Tabin (1996) Biochemical evidence that patched is the Hedgehog receptor. Nature, 384, 176-9.

May, S. R., A. M. Ashique, M. Karlen, B. Wang, Y. Shen, K. Zarbalis, J. Reiter, J. Ericson \& A. S. Peterson (2005) Loss of the retrograde motor for IFT disrupts localization of Smo to cilia and prevents the expression of both activator and repressor functions of Gli. Dev Biol, 287, 378-89.

Mill, P., R. Mo, H. Fu, M. Grachtchouk, P. C. Kim, A. A. Dlugosz \& C. C. Hui (2003) Sonic hedgehog-dependent activation of Gli2 is essential for embryonic hair follicle development. Genes Dev, 17, 282-94.

Mille, F., C. Thibert, J. Fombonne, N. Rama, C. Guix, H. Hayashi, V. Corset, J. C. Reed \& P. Mehlen (2009) The Patched dependence receptor triggers apoptosis through a DRAL-caspase-9 complex. Nat Cell Biol, 11, 739-46.

Motoyama, J., H. Heng, M. A. Crackower, T. Takabatake, K. Takeshima, L. C. Tsui \& C. Hui (1998) Overlapping and non-overlapping Ptch2 expression with Shh during mouse embryogenesis. Mech Dev, 78, 81-4.

Nieuwenhuis, E., J. Motoyama, P. C. Barnfield, Y. Yoshikawa, X. Zhang, R. Mo, M. A. Crackower \& C. C. Hui (2006) Mice with a targeted mutation of patched2 are viable but develop alopecia and epidermal hyperplasia. Mol Cell Biol, 26, 660922.

Nieuwenhuis, E., P. C. Barnfield, S. Makino \& C.-c. Hui (2007) Epidermal hyperplasia and expansion of the interfollicular stem cell compartment in mutant mice with a Cterminal truncation of Patched1. Dev Biol, 308, 547-60.

Okada, A., F. Charron, S. Morin, D. S. Shin, K. Wong, P. J. Fabre, M. Tessier-Lavigne \& S. K. McConnell (2006) Boc is a receptor for sonic hedgehog in the guidance of commissural axons. Nature, 444, 369-73.

Oro, A. E. \& K. Higgins (2003) Hair cycle regulation of Hedgehog signal reception. Dev Biol, 255, 238-48.

Oro, A. E., K. M. Higgins, Z. Hu, J. M. Bonifas, E. H. Epstein, Jr. \& M. P. Scott (1997) Basal cell carcinomas in mice overexpressing sonic hedgehog. Science, 276, 817-21.

Ponten, F., C. Berg, A. Ahmadian, Z. P. Ren, M. Nister, J. Lundeberg, M. Uhlen \& J. Ponten (1997) Molecular pathology in basal cell cancer with p53 as a genetic marker. Oncogene, 15, 1059-67. 
Reichrath, J. 2006. Molecular mechanisms of basal cell and squamous cell carcinomas. Georgetown, Tex. New York, N.Y.: Landes Bioscience/Eurekah.com; Springer Science+Business Media.

Reifenberger, J., M. Wolter, C. B. Knobbe, B. Kohler, A. Schonicke, C. Scharwachter, K. Kumar, B. Blaschke, T. Ruzicka \& G. Reifenberger (2005) Somatic mutations in the $\mathrm{PTCH}, \mathrm{SMOH}, \mathrm{SUFUH}$ and TP53 genes in sporadic basal cell carcinomas. $\mathrm{Br} \mathrm{J}$ Dermatol, 152, 43-51.

Ruiz i Altaba, A. 2006. Hedgehog-gli signaling in human disease. Georgetown, Tex. New York, N.Y.: Landes Bioscience/Eurekah.com; Springer Science+Business Media.

Smyth, I., M. A. Narang, T. Evans, C. Heimann, Y. Nakamura, G. Chenevix-Trench, T. Pietsch, C. Wicking \& B. J. Wainwright (1999) Isolation and characterization of human patched 2 (PTCH2), a putative tumour suppressor gene inbasal cell carcinoma and medulloblastoma on chromosome 1p32. Hum Mol Genet, 8, 2917.

Svard, J., K. Heby-Henricson, M. Persson-Lek, B. Rozell, M. Lauth, A. Bergstrom, J. Ericson, R. Toftgard \& S. Teglund (2006) Genetic elimination of Suppressor of fused reveals an essential repressor function in the mammalian Hedgehog signaling pathway. Dev Cell, 10, 187-97.

Sweet, H. O., R.T. Bronson, L. R. Donahue \& M. T. Davisson (1996) Mesenchymal dysplasia: A recessive mutation on chromosome 13 of the mouse. J Hered, 87, 87-95.

Taipale, J., M. K. Cooper, T. Maiti \& P. A. Beachy (2002) Patched acts catalytically to suppress the activity of Smoothened. Nature, 418, 892-7.

Teh, M. T., D. Blaydon, T. Chaplin, N. J. Foot, S. Skoulakis, M. Raghavan, C. A. Harwood, C. M. Proby, M. P. Philpott, B. D. Young \& D. P. Kelsell (2005) Genomewide single nucleotide polymorphism microarray mapping in basal cell carcinomas unveils uniparental disomy as a key somatic event. Cancer Res, 65, 8597-603.

Thibert, C., M. A. Teillet, F. Lapointe, L. Mazelin, N. M. Le Douarin \& P. Mehlen (2003) Inhibition of neuroepithelial patched-induced apoptosis by sonic hedgehog. Science, 301, 843-6.

Tukachinsky, H., L. V. Lopez \& A. Salic (2010) A mechanism for vertebrate Hedgehog signaling: recruitment to cilia and dissociation of $\mathrm{SuFu}-\mathrm{Gli}$ protein complexes. J Cell Biol, 191, 415-28.

Villani, R. M., C. Adolphe, J. Palmer, M. J. Waters \& B. J. Wainwright (2010) Patched1 inhibits epidermal progenitor cell expansion and basal cell carcinoma formation by limiting Igfbp2 activity. Cancer Prev Res (Phila), 3, 1222-34.

Wakabayshi, Y., J. H. Mao, K. Brown, M. Girardi \& A. Balmain (2007) Promotion of Hrasinduced squamous carcinomas by a polymorphic variant of the Patched gene in FVB mice. Nature, 445, 761-765.

Wang, G. Y., J. Wang, M. L. Mancianti \& E. H. Epstein, Jr. (2011) Basal cell carcinomas arise from hair follicle stem cells in Ptch1(+/-) mice. Cancer Cell, 19, 114-24.

Wong, S. Y. \& J. F. Reiter (2011) Wounding mobilizes hair follicle stem cells to form tumors. Proc Natl Acad Sci U S A, 108, 4093-8. 
Wong, S. Y., A. D. Seol, P. L. So, A. N. Ermilov, C. K. Bichakjian, E. H. Epstein, Jr., A. A. Dlugosz \& J. F. Reiter (2009) Primary cilia can both mediate and suppress Hedgehog pathway-dependent tumorigenesis. Nat Med, 15, 1055-61.

Xie, J., M. Murone, S. M. Luoh, A. Ryan, Q. Gu, C. Zhang, J. M. Bonifas, C. W. Lam, M. Hynes, A. Goddard, A. Rosenthal, E. H. Epstein, Jr. \& F. J. de Sauvage (1998) Activating Smoothened mutations in sporadic basal-cell carcinoma. Nature, 391, 90-2.

Yam, P. T., S. D. Langlois, S. Morin \& F. Charron (2009) Sonic hedgehog guides axons through a noncanonical, Src-family-kinase-dependent signaling pathway. Neuron, $62,349-62$.

Youssef, K. K., A. Van Keymeulen, G. Lapouge, B. Beck, C. Michaux, Y. Achouri, P. A. Sotiropoulou \& C. Blanpain (2010) Identification of the cell lineage at the origin of basal cell carcinoma. Nat Cell Biol, 12, 299-305.

Zhang, H., X. L. Ping, P. K. Lee, X. L. Wu, Y. J. Yao, M. J. Zhang, D. N. Silvers, D. Ratner, R. Malhotra, M. Peacocke \& H. C. Tsou (2001) Role of PTCH and p53 genes in earlyonset basal cell carcinoma. Am J Pathol, 158, 381-5.

Zibat, A., A. Uhmann, F. Nitzki, M. Wijgerde, A. Frommhold, T. Heller, V. Armstrong, L. Wojnowski, L. Quintanilla-Martinez, J. Reifenberger, W. Schulz-Schaeffer \& H. Hahn (2009) Time-point and dosage of gene inactivation determine the tumor spectrum in conditional Ptch knockouts. Carcinogenesis, 30, 918-26. 


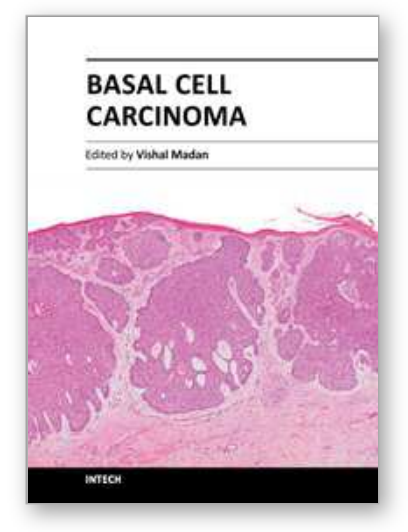

\author{
Basal Cell Carcinoma \\ Edited by Dr. Vishal Madan
}

ISBN 978-953-51-0309-7

Hard cover, 126 pages

Publisher InTech

Published online 14, March, 2012

Published in print edition March, 2012

Basal cell carcinoma is the commonest cutaneous malignancy. The last decade has witnessed exponential research which has broadened our understanding of the pathogenesis of basal cell carcinomas. This is also important from a therapeutic point of view as targeted approach to therapy is now being increasingly experimented. Although it is impossible to condense and present all good research in one book, the authors have to be commended on presenting their research on several aspects of basal cell carcinoma in a succinct manner, which shall not only enhance our understanding of, but also hopefully via this open exchange of ideas pave ways for successful targeted therapy of the commonest human cancer.

\title{
How to reference
}

In order to correctly reference this scholarly work, feel free to copy and paste the following:

Zhu Juan Li and Chi-chung Hui (2012). BCC and the Secret Lives of Patched: Insights from Patched Mouse Models, Basal Cell Carcinoma, Dr. Vishal Madan (Ed.), ISBN: 978-953-51-0309-7, InTech, Available from: http://www.intechopen.com/books/basal-cell-carcinoma/patching-the-gap-between-hh-signaling-and-bccinsights-from-transgenic-mouse-models

\section{INTECH}

open science | open minds

\section{InTech Europe}

University Campus STeP Ri Slavka Krautzeka 83/A 51000 Rijeka, Croatia Phone: +385 (51) 770447

Fax: +385 (51) 686166 www.intechopen.com

\section{InTech China}

Unit 405, Office Block, Hotel Equatorial Shanghai No.65, Yan An Road (West), Shanghai, 200040, China 中国上海市延安西路65号上海国际贵都大饭店办公楼 405 单元 Phone: +86-21-62489820

Fax: +86-21-62489821 
(C) 2012 The Author(s). Licensee IntechOpen. This is an open access article distributed under the terms of the Creative Commons Attribution 3.0 License, which permits unrestricted use, distribution, and reproduction in any medium, provided the original work is properly cited. 